\title{
JARINGAN SYARAF TIRUAN UNTUK MEMPREDIKSI KINERJA SATPAM
}

\author{
Muhammad Fachrie'), Adityo Permana Wibowo ${ }^{2)}$ \\ ${ }^{1,2)}$ Program Studi Teknik Informatika, Universitas Teknologi Yogyakarta \\ Ringroad Utara, Jombor, Sleman, Yogyakarta \\ e-mail: muhammad.fachrie@ staff.uty.ac.id ${ }^{1)}$, adityopw@uty.ac.id²)
}

\begin{abstract}
ABSTRAK
Penilaian kinerja karyawan merupakan salah satu hal yang sangat penting dilakukan oleh pihak manajemen Sumber Daya Manusia (SDM) dalam suatu instansi, sebab aspek tersebut menjadi faktor penentu bagi para pengambil kebijakan untuk menaikkan jenjang karier dari para karyawannya atau tidak. Artikel ini menyajikan analisis terhadap penggunaan Multi Layer Perceptron (MLP) untuk memprediksi kinerja Satuan Pengamanan (Satpam) yang telah dididik oleh suatu instansi resmi. Data yang digunakan diperoleh secara langsung dari PT. Garuda Merah Indonesia, yakni lembaga pendidik dan pelatih calon Satpam, sebanyak 175 record dengan 10 atribut yang meliputi penilaian terhadap individu dalam aspek kemampuan kognitif, kepribadian, dan keterampilan. MLP memprediksi kinerja Satpam ke dalam tiga kategori, yakni "Baik”, "Cukup”, dan "Kurang”. Teknik Cross Validation sebanyak 10 fold juga digunakan pada tahap pengujian sistem untuk mengukur performa sistem secara komprehensif dengan keluaran berupa tingkat akurasi terbaik sebesar 97,75\%.
\end{abstract}

Kata Kunci: prediksi kinerja karyawan, jaringan syaraf tiruan, multi layer perceptron, data mining

\begin{abstract}
Employee performance assessment is a very important task that has to be performed by Human Resource Department in a certain institution, because it would be useful for the policy holders to help them making a decision in promoting or not their employees. This paper delivered the analysis of using Multi Layer Perceptron (MLP) to predict the performance of security unit personnels which has been trained by a formal institution. The data that was used in this research were collected from PT. Garuda Merah Indonesia, that is a company that has role to train and to educate people who wants to be a security personnel. The data consist of 175 record with 10 attributes which include the assessment from aspects of cognitive, personality, and skill. MLP predicted the security personnel performances into three categories, i.e. "Good", "Enough", and "Fail". The 10 folds Cross Validation technique was also used in testing phase to measure its performance comprehensively with the output of the best accuracy was $97,75 \%$.
\end{abstract}

Keywords: employee performance's prediction, artificial neural network, multilayer perceptron, data mining

\section{PENDAhUluan}

$\mathrm{P}$ engelolaan Sumber Daya Manusia (SDM) merupakan hal yang krusial di dalam suatu lembaga atau perusahaan, sebab SDM merupakan aset vital bagi sebuah perusahaan. Kualitas SDM yang baik tentu akan berimbas pada produktivitas lembaga atau perusahaan. Selain itu, pemegang kebijakan di level atas, terutama di dalam sebuah perusahaan, tentunya membutuhkan data-data pendukung ketika akan mempromosikan karyawan atau stafnya ke jenjang yang lebih tinggi atau sebaliknya menurunkan ke jenjang yang lebih rendah. Tentunya ongkos yang dikeluarkan untuk memberikan penilaian secara manual pada setiap SDM. Solusi yang bisa ditawarkan terhadap hal tersebut adalah membangun sistem otomasi yang mampu memberikan data-data pendukung berupa penilaian kinerja para karyawan secara real time sebagai bahan pertimbangan dalam menaikkan atau menurunkan level karier SDM dalam di perusahaan.

Sistem pendukung keputusan semacam ini dapat dibangun dengan memanfaatkan teknik Data Mining yang mampu mempelajari pola dari sekumpulan data dan menghasilkan informasi dan pengetahuan (knowledge) yang bermanfaat [1]. Pada penelitian ini, metode Data Mining yang digunakan merupakan metode yang telah dikenal memiliki performa yang baik, bahkan sangat baik untuk beberapa kasus, yakni Jaringan Syaraf Tiruan (JST) yakni sebuah metode komputasi yang mengadaptasi model pemrosesan informasi di dalam sel syaraf otak manusia [2-3]. JST tersebut memprediksi kinerja Satuan Pengamanan (Satpam) dan mengklasifikasikannya ke dalam salah satu dari tiga kategori, yakni "Baik", "Cukup", dan "Buruk".

Artikel ini disusun dengan sistematika sebagai berikut: bagian kedua menguraikan penelitian-penelitian terdahulu di bidang serupa, bagian ketiga mendeskripsikan data yang digunakan di dalam penelitian, bagian keempat berisi tentang metode utama yang digunakan dalam penelitian, kemudian bagian kelima menguraikan hasil penelitian beserta analisisnya, lalu ditutup oleh bagian keenam yang berisi kesimpulan.

Peneliti terdahulu, Wibowo dan Hartati, telah membangun sistem dengan data serupa menggunakan teknik Naive Bayes Classifier (NBC) untuk memprediksi kinerja Satpam [4]. Performa sistem yang dihasilkan cukup baik, yakni mencapai tingkat akurasi sebesar 92,31\%. Namun, pengujian yang dilakukan kurang menampilkan performa sistem 
secara komprehensif sebab pemilihan data latih dan data uji tidak melibatkan teknik Cross Validation, sehingga sistem tidak pernah diuji dengan variasi data latih dan data uji yang berbeda. Metode yang sama juga digunakan oleh Ulfa Pauziah untuk menentukan karyawan terbaik di suatu perusahaan [5]. Akurasi yang diperoleh tergolong tinggi, yakni $98,57 \%$, namun pengujian yang dilakukan menggunakan data dalam jumlah yang cukup sedikit, yakni hanya 70 record (dengan 6 atribut) yang diuji lewat metode cross validation.

Kotalwar, dkk. [6], Kalaivani dan Elamparithi [7], serta Defiyanti [8] memanfaatkan metode Decision Tree untuk memprediksi kinerja karyawan dan mahasiswa. Keuntungan yang diperoleh dari metode Decision Tree adalah aturan-aturan penalaran yang dapat diketahui, sehingga hasil klasifikasi atau prediksinya dapat ditelusuri alasanalasannya. Namun, hal penting yang menjadi kelemahan dari metode ini adalah model pohon keputusan yang dihasilkan berpotensi menghasilkan sistem yang overfit, yakni akurat memprediksi data latih, namun buruk akurasinya ketika memprediksi data uji. Meskipun hal tersebut sebenarnya dapat diatasi dengan teknik pruning.

Di dalam penelitian yang dilakukan oleh Jantan, dkk. [9], beberapa teknik Data Mining, yakni Decision Tree (C4.5), Random Forest, Multi Layer Perceptron (MLP), Radial Basis Function (RBF), dan K-Star, dibandingkan performannya satu sama lain. Pada penelitian tersebut tercatat bahwa Decision Tree memperoleh akurasi tertinggi, terpaut 9\% dari MLP yang hanya memperoleh akurasi terendah yakni hanya sebesar $70.25 \%$. Meskipun demikian, performa MLP sebenarnya dapat diperbaiki dengan mengatur arsitektur dan parameter learning-nya dengan cara melakukan observasi kecil untuk menemukan kombinasi arsitektur dan parameter MLP yang tepat.

\section{MetODE}

\section{A. Multi Layer Perceptron}

Multilayer Perceptron (MLP) merupakan model Artificial Neural Network (ANN) yang sudah sangat popular digunakan oleh banyak peneliti untuk berbagai keperluan, seperti pengenalan tulisan tangan, pengenalan wajah, pengenalan suara, prediksi timeseries, dsb. Arsitektur dari sebuah MLP, sebagaimana yang ditampilkan pada gambar 1, terdiri dari tiga lapisan neuron, yakni -secara terurut- input layer, hidden layer, dan output layer, dimana di setiap layer tersebut berisi sejumlah neuron yang saling terhubung dengan neuron lainnya pada lapisan setelahnya.

Input layer berisi nilai-nilai masukan yang akan diproses oleh MLP, hidden layer bertugas sebagai penghubung/ lapisan antara input layer dan output layer. Keberadaan hidden layer inilah yang menjadikan MLP mampu melakukan klasifikasi data yang sifatnya nonlinear separable. Koneksi antar satu layer dengan layer lainnya (yang digambarkan dengan garis antar neuron) memiliki bobot nilai masing-masing, dimana semakin besar nilai bobotnya, maka semakin besar peluang suatu data/ informasi diteruskan ke neuron pada layer berikutnya.

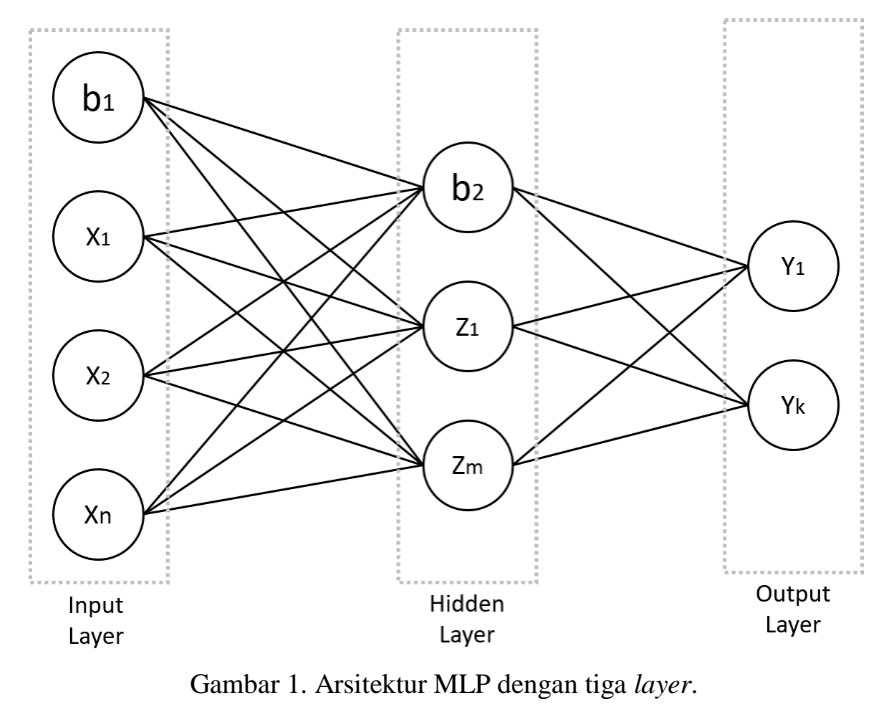

MLP mampu mempelajari dan mengenali suatu pola berdasarkan pengetahuan yang ia dapatkan melalui proses pelatihan yang disebut Backpropagation. Setiap kali MLP melakukan proses pelatihan, maka bobot-bobot jaringan (weights) yang menghubungkan neuron-neuron pada tiap lapisan akan diperbarui. Setiap neuron pada hidden layer dan output layer melakukan proses kalkulasi untuk mendapatkan output berupa nilai aktivasi menggunakan fungsi aktivasi sigmoid yang dirumuskan oleh persamaan (1). 


$$
f(n e t)=\frac{1}{1+e x p^{-n e t}}
$$

dimana,

$$
n e t=\sum_{i=1}^{n} x_{i} \cdot w_{i j}+b_{i}
$$

$x$ adalah vektor input, $w$ adalah vektor bobot yang menghubungkan dua lapisan, dan $b$ adalah nilai bias. Proses penghitungan tersebut dilakukan secara bertahap, yakni dimulai dari menghitung nilai aktivasi dari setiap neuron pada hidden layer, kemudian nilai tersebut dijadikan input untuk proses kalkulasi nilai aktivasi pada output layer.

\section{B. Cross Validation}

Teknik Cross Validation merupakan strategi pengujian sistem yang sangat populer, dimana data penelitian dibagi ke dalam dua bagian, yakni data latih dan data uji. dengan ketentuan bahwa pembagian tersebut dilakukan beberapa fase (fold) [11]. Teknik ini menjamin bahwa hasil pengukuran/ pengujian terhadap suatu algoritma valid, sebab algoritma tersebut telah dilatih dan diuji menggunakan variasi data yang bermacam-macam, dan tentunya kedua bagian data tersebut saling independen. Gambar 2 memberikan ilustrasi mengenai cara kerja teknik Cross Validation dengan tiga kali fase pembagian data (3 folds).

\section{HASIL}

\section{A. Deskripsi Data}

Penelitian yang melibatkan Jaringan Syaraf Tiruan (JST), apapun arsitektur jaringannya, membutuhkan sekumpulan data histori yang digunakan sebagai bahan pembelajaran (learning) bagi JST untuk mengenali polapola datanya. Semakin besar jumlah data yang digunakan, tentunya waktu komputasi pada tahap learning pun akan bertambah, namun performa sistem akan cenderung lebih baik.

Pada penelitian ini, data mentah yang digunakan diperoleh dari penelitian sebelumnya yang dilakukan oleh Wibowo dan Hartati [4], yakni berupa data kinerja Satpam dari PT. Garuda Merah Indonesia sebanyak 175 record dan 12 atribut/ kolom yang terdiri dari aspek penilaian kemampuan individu Satpam meliputi kecerdasan kognitif, kepribadian, dan keterampilan. Dari keseluruhan atribut data mentah yang disajikan pada Tabel 1, atribut pertama (nama Satpam) tidak digunakan dalam eksperimen, sebab nama seseorang tidak memiliki korelasi apapun terhadap kinerja individu. Atribut ke-2 s.d. ke-11 digunakan sebagai input bagi sistem, yakni MLP, untuk memprediksi kinerja tiap Satpam. Lalu, atribut terakhir (kinerja) digunakan sebagai target, yakni acuan belajar bagi MLP untuk melakukan koreksi bobot jaringan pada saat proses learning.

TABEL I.

DESKRIPSI DATA MENTAH YANG DIGUNAKAN DALAM PENELITIAN

\begin{tabular}{cccccc}
\hline \hline No. & Nama Atribut & Tipe Data & Rentang Nilai & Rata-rata & Std. Deviasi \\
\hline 1 & Nama Satpam & String & - & - & - \\
2 & Kecerdasan Verbal & Integer & {$[0,10]$} & 5,60 & 2,08 \\
3 & Kecerdasan Numerik & Integer & {$[0,5]$} & 4,25 & 0,87 \\
4 & Kecerdasan Spasial & Integer & {$[0,5]$} & 2,62 & 1,31 \\
5 & Kebanggaan & Integer & {$[13,20]$} & 17,7 & 1,32 \\
6 & Kualitas Hidup & Integer & {$[45,74]$} & 61,0 & 4,98 \\
7 & Affective Commitment & Integer & {$[7,23]$} & 16,2 & 2,46 \\
8 & Continuance Commitment & Integer & {$[5,12]$} & 8,77 & 1,70 \\
9 & Normative Commitment & Integer & {$[13,32]$} & 23,3 & 2,84 \\
10 & Tanggung Jawab & Integer & {$[26,44]$} & 38,6 & 3,18 \\
11 & Keterampilan & Integer & {$[0,5]$} & 2,82 & 1,12 \\
12 & Kinerja & Integer & {$[0,2]$} & 1,07 & 0,57 \\
\hline \hline
\end{tabular}

\section{B. Prapemrosesan Data}

Data mentah yang diperoleh tidak dapat langsung digunakan untuk penelitian, sebab ada beberapa atribut yang memerlukan penyesuaian terlebih dahulu agar dapat diproses oleh MLP. Data yang dapat diproses oleh MLP adalah data bertipe numerik, sehingga data-data yang masih dalam bentuk string atau char harus dikonversi terlebih dahulu menjadi numerik. Kemudian, setelah data tersebut dipastikan telah bertipe numerik, maka selanjutnya adalah 
melakukan normalisasi pada nilai-nilai data dari setiap atribut yang memiliki nilai data yang sangat besar, misalnya ratusan, ribuan, bahkan jutaan. Normalisasi tersebut dilakukan dengan cara mengkonversi nilai dari suatu atribut data ke dalam rentang nilai tertentu, misalnya $[0,1]$ atau $[-1,1]$. Kenapa hal ini perlu dilakukan? Jawabannya adalah karena MLP (atau ANN secara umum) hanya bisa menghasilkan nilai dalam rentang $[0,1]$ atau $[-1,1]$.

Di dalam penelitian ini, normalisasi data dilakukan menggunakan metode min-max, yakni dengan mengkonversi nilai data pada setiap atribut ke dalam rentang [-1,1] menggunakan persamaan (1) [10].

$$
x_{i}^{\prime}=\frac{\left(x_{i}-\min _{a}\right)}{\left(\max _{a}-\min _{a}\right)}\left(\operatorname{maxBaru}_{a}-\operatorname{minBaru}_{a}\right)+\operatorname{minBaru}_{a}
$$

dimana $x^{\prime}{ }_{i}$ adalah data pada indeks ke-i hasil normalisasi, $x$ adalah data/ nilai awal pada indeks ke- $i$ sebelum normalisasi, $\min _{a}$ adalah nilai terkecil dari atribut ke- $a, \max _{a}$ adalah nilai terbesar dari atribut ke- $a, \operatorname{maxBar}_{a}$ adalah nilai terbesar yang baru (pada penelitian ini: 1) untuk atribut ke- $a$, dan minBaru $_{a}$ adalah nilai terkecil yang baru (yakni: -1) untuk atribut ke- $a$. Metode ini menjamin bahwa semua nilai dari masing-masing atribut dikonversi ke dalam rentang nilai $\left[\operatorname{minBaru}_{a}, \operatorname{maxBaru}_{a}\right]$.

\section{Pelatihan dan Pengujian MLP}

Untuk mengukur performa MLP secara komprehensif, teknik Cross Validation diimplementasikan sebanyak tiga kali dengan variasi $\mathrm{k}=3, \mathrm{k}=5$, dan $\mathrm{k}=10$. Pembagian data untuk setiap nilai tersebut dilakukan secara acak dengan tetap memperhatikan proporsi data untuk tiap-tiap kelas.

Arsitektur MLP dibuat dalam dua skenario besar, skenario pertama menggunakan satu hidden layer dan skenario kedua menggunakan dua hidden layer. Nilai learning rate (LR) diset sebesar 0,1; momentum diset sebesar 0,2; dan jumlah maksimum epoch sebanyak 1000 iterasi. Hasil pelatihan dan pengujian dari setiap scenario tersaji di dalam Tabel II.

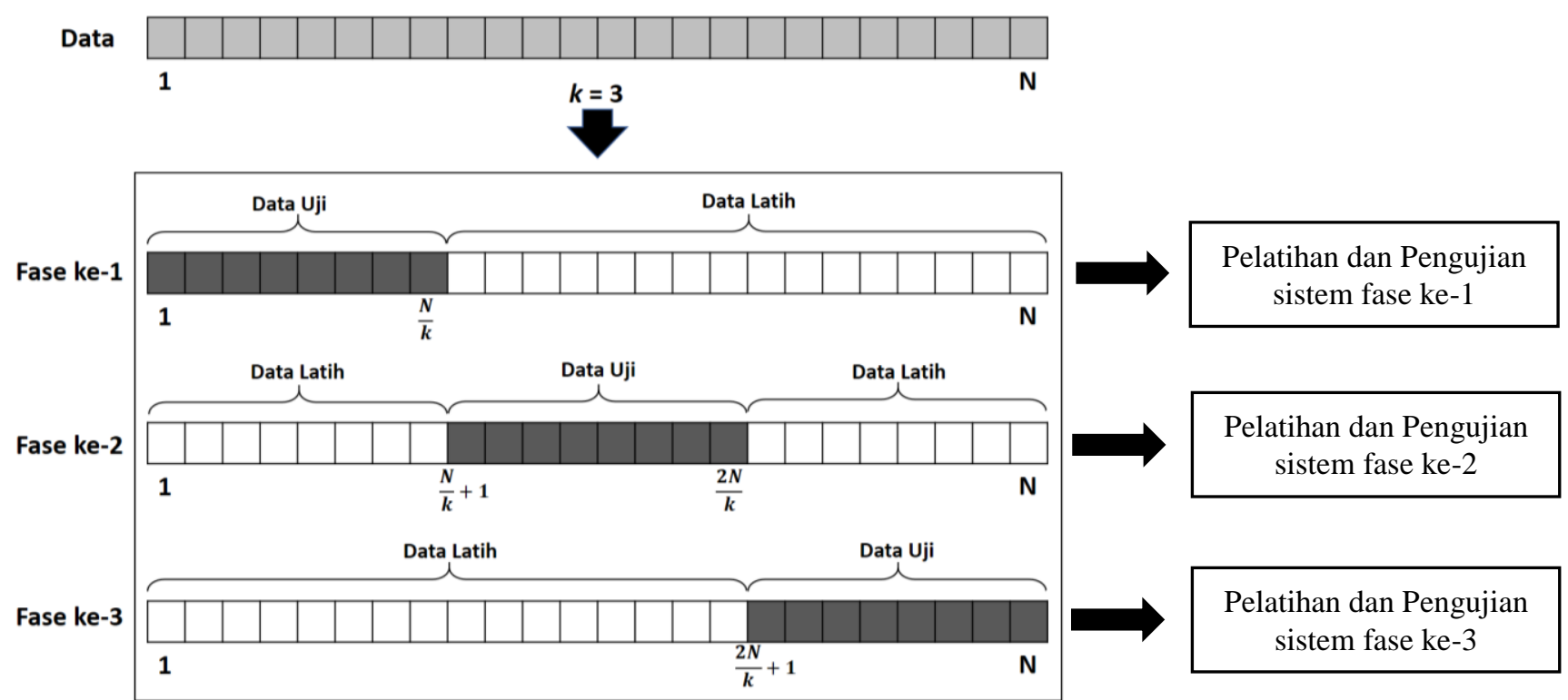

Gambar 2. Ilustrasi proses pembagian data dengan teknik Cross Validation

Hasil eksperimen ini menunjukkan bahwa rata-rata tingkat akurasi tertinggi yang dicapai adalah 96,59\% pada arsitektur 10-10-3-3. Pada studi kasus ini ternyata MLP dengan dua hidden layer mampu menghasilkan sistem yang lebih baik daripada MLP dengan satu hidden layer, dengan peningkatan hingga 4\%. Hal ini disebabkan MLP dengan dua hidden layer mampu mengelompokkan data yang sebarannya sangat kompleks. Namun, hal yang menjadi catatan adalah, semakin banyak neuron yang dipakai tidak berbanding lurus dengan peningkatan performa MLP. Hal ini bisa dilihat pada saat menggunakan arsitektur 10-13-3 atau 10-11-3, ternyata hasilnya tidak lebih baik dari arsitektur 10-3-3 atau 10-5-3 yang jauh lebih sedikit jumlah neuronnya. Sedangkan pada MLP dengan dua hidden layer, komposisi neuron yang digunakan memiliki probabilitas yang cukup besar, karena ada dua hidden layer yang perlu ditentukan jumlah neuronnya, oleh karena itu, untuk membatasi area kerja, maka jumlah neuron pada setiap lapisan dibuat lebih kecil/ sedikit daripada jumlah neuron pada lapisan sebelumnya. 
TABEL II.

DATA HASIL PENGUJIAN MLP DENGAN BEBERAPA SKENARIO

\begin{tabular}{|c|c|c|c|c|c|c|c|}
\hline \multicolumn{4}{|c|}{ MLP dengan satu hidden layer } & \multicolumn{4}{|c|}{ MLP dengan dua hidden layer } \\
\hline k-fold & Arsitektur MLP & Akurasi & Rerata Akurasi & k-fold & Arsitektur MLP & Akurasi & Rerata Akurasi \\
\hline 3 & $10-13-3$ & $88,65 \%$ & $87,84 \%$ & 3 & $10-10-5-3$ & $90,29 \%$ & $88,16 \%$ \\
\hline 5 & & $86,29 \%$ & & 5 & & $86,29 \%$ & \\
\hline 10 & & $88,59 \%$ & & 10 & & $87,91 \%$ & \\
\hline 3 & $10-11-3$ & $88,09 \%$ & $88,02 \%$ & 3 & $10-10-3-3$ & $95,44 \%$ & $96,59 \%$ \\
\hline 5 & & $90,29 \%$ & & 5 & & $96,57 \%$ & \\
\hline 10 & & $85,69 \%$ & & 10 & & $97,75 \%$ & \\
\hline 3 & $10-9-3$ & $88,65 \%$ & $89,75 \%$ & 3 & $10-9-5-3$ & $85,77 \%$ & $87,43 \%$ \\
\hline 5 & & $92,57 \%$ & & 5 & & $90,29 \%$ & \\
\hline 10 & & $88,04 \%$ & & 10 & & $86,24 \%$ & \\
\hline 3 & $10-7-3$ & $88,65 \%$ & $90,52 \%$ & 3 & $10-9-3-3$ & $95,44 \%$ & $96,38 \%$ \\
\hline 5 & & $92,57 \%$ & & 5 & & $97,14 \%$ & \\
\hline 10 & & $90,33 \%$ & & 10 & & $96,57 \%$ & \\
\hline 3 & $10-5-3$ & $89,22 \%$ & $91,66 \%$ & 3 & $10-8-5-3$ & $93,74 \%$ & $89,53 \%$ \\
\hline 5 & & $92,57 \%$ & & 5 & & $89,71 \%$ & \\
\hline 10 & & $93,20 \%$ & & 10 & & $85,13 \%$ & \\
\hline 3 & $10-3-3$ & $88,65 \%$ & $\underline{92,62 \%}$ & 3 & $10-8-3-3$ & $96,02 \%$ & $95,63 \%$ \\
\hline 5 & & $92,57 \%$ & & 5 & & $93,14 \%$ & \\
\hline 10 & & $96,63 \%$ & & 10 & & $97,75 \%$ & \\
\hline
\end{tabular}

\section{PEMBAHASAN}

\section{Perbandingan Performa}

Sistem yang dibuat pada penelitian ini telah dibandingkan dengan beberapa teknik klasifikasi lainnya dalam hal performanya. Pengujian pada tahap ini masih melibatkan Cross Validation dengan variasi nilai k yang sama pada tahap sebelumnya.

Data perbandingan akurasi pada Tabel 3 menunjukkan bahwa MLP pada penelitian ini memiliki performa yang jauh lebih baik daripada teknik klasifikas lainnya. Bahkan, selain MLP, tidak ada teknik klasifikasi yang mencapai tingkat akurasi hingga 90\%. Namun begitu, hal ini tidak mutlak, artinya dalam beberapa kasus lain bisa saja teknik klasifikasi lain lebih baik dan lebih tepat digunakan ketimbang menggunakan MLP. Misalnya pada sistem prediksi pemberian kredit bagi nasabah bank yang memerlukan alasan-alasan logis terhadap setiap penerimaan atau penolakan permohonan, MLP mungkin tidak lebih baik ketimbang Random Forest ataupun metode Decision Tree (DT) lainnya, sebab DT mampu memberikan reason terhadap output yang dihasilkan, yang mana MLP tidak mampu untuk hal tersebut.

TABEL III.

PERBANDINGAN AKURASI ANTARA MLP DENGAN BEBERAPA TEKNIK KLASIFIKASI LAINNYA

\begin{tabular}{cccccc}
\hline \hline \multirow{2}{*}{ No. } & Teknik Klasifikasi & \multicolumn{3}{c}{ Akurasi } & \multirow{2}{*}{ Rata-rata akurasi } \\
\cline { 3 - 5 } & & $\boldsymbol{k}$-fold $=\mathbf{3}$ & $\boldsymbol{k}$-fold =5 & $\boldsymbol{k}$-fold= 10 & \\
\hline 1 & Naïve Bayes & $82,39 \%$ & $88,57 \%$ & $86,24 \%$ & $85,73 \%$ \\
2 & Support Vector Machine & $84,05 \%$ & $87,43 \%$ & $86,86 \%$ & $86,11 \%$ \\
3 & K-NN (k=5) & $80,64 \%$ & $84,00 \%$ & $83,43 \%$ & $82,69 \%$ \\
4 & Random Forest & $72,65 \%$ & $70,86 \%$ & $71,41 \%$ & $71,64 \%$ \\
5 & Multilayer Perceptron & $\underline{\mathbf{9 5 , 4 4 \%}}$ & $\underline{\mathbf{9 6 , 5 7 \%}}$ & $\underline{\mathbf{9 7 , 7 5 \%}}$ & $\underline{\mathbf{9 6 , 5 9 \%}}$ \\
\hline \hline
\end{tabular}

\section{SIMPULAN DAN SARAN}

Penelitian yang telah dilakukan mampu menunjukkan performa yang baik dari Multilayer Perceptron (MLP), terutama jika dibandingkan dengan beberapa teknik klasifikasi lainnya. Adapun kesimpulan yang bisa diambil dari hasil penelitian ini antara lain:

1. MLP mampu mengklasifikasikan data kinerja Satpam dengan akurasi tertinggi sebesar $97,75 \%$ dan rata-rata akurasi tertinggi sebesar 96,59\%.

2. MLP dengan dua hidden layer memiliki kemampuan klasifikasi yang lebih baik pada data yang bersifat 
complex daripada MLP dengan hanya satu hidden layer.

3. Pada penelitian ini, MLP menunjukkan kinerja yang lebih baik daripada teknik klasifikasi lainnya, seperti Naïve Bayes, SVM, K-NN, dan Random Forest.

Sebagai saran untuk penelitian berikutnya, sebaiknya arsitektur MLP dieksplorasi lebih dalam lagi, terutama parameter learning seperti learning rate, momentum, dan jumlah iterasi maksimal yang digunakan.

\section{REFERENSI}

[1] J. Han and M. Kamber, Data Mining: Concepts and Techniques - Second Edition, CA: Morgan Kauffmann, 2006.

[2] S. Haykin, Neural Network and Learning Machines - Third Edition, New Jersey: Pearson Prentice Hall, 2009.

[3] L.V. Fausett and E. Cliffs, Fundamentals of Neural Networks: Architectures, Algorithms, and Applications, New Jersey: Prentice Hall, 1994.

[4] A.P. Wibowo and S. Hartati, "Sistem klasifikasi kinerja satpam menggunakan metode naive bayes classifier," Jurnal Inovasi Teknologi Politeknik Bengkaslis - Seri Informatika, vol. 1(2), pp. 192-201, 2016.

[5] U. Pauziah, "Analisis penentuan karyawan terbaik menggunakan Metode Algoritma Naive Bayes (Studi Kasus PT. XYZ),” Prosiding Diskusi Panel Pendidikan "Menjadi Guru Pembelajar", Jakarta, April 2017.

[6] R. Kotalwar, R. Chavan, S. Gandhi, and V. Parmar, "Data Mining: Evaluating Performance of Employee's using Classification Algorithm Based on Decision Tree," Engineering Science and Technology: An International Journal, vol. 4(2), pp. 29-35. 2014.

[7] S. Defiyanti, “Analisis dan Prediksi Kinerja Mahasiswa Menggunakan Teknik Data Mining,” Syntax Jurnal Informatika, vol. 2(2), pp. 1-8, 2013.

[8] V. Kalaivani and Elamparithi, "An Efficient Classification Algorithms for Employee Performance Prediction,” International Journal of Research in Advance Technology, vol. 2(9), pp. 27-32, 2014.

[9] H. Jantan, R. Hamdan., A.R. Othman, and Z.A. Othman, “Applying Data Mining Classification Techniques for Employee's Performance Prediction,” Proceeding of Knowledge Management 5th Int'l Conference, Malaysia. 2010.

[10] Suyanto. Data Mining untuk Klasifikasi dan Klasterisasi, Bandung: Informatika, 2017.

[11] S. Arlot. "A survey of cross-validation procedures for model selection”, Statistics Survey, vol. 4, pp. 40-79, 2010. 